\title{
Poetry as an Act of International Diplomacy: English translations of Willem van Haren's Political Poetry during the War of the Austrian Succession
}

\author{
LOTTE JENSEN and MARGUERITE CORPORAAL
}

\begin{abstract}
In the eighteenth century the worlds of diplomacy and poetry were inextricably connected. This is demonstrated by the work of the Dutch statesman and poet Willem van Haren (I7IO-I768), whose political poems played an important role in the negotiations of international political relations during the War of the Austrian Succession. Several poems were translated into English by the Irish poet Samuel Boyse and published in The Gentleman's Magazine. It is argued that the great interest in Van Haren's work in England can be clarified by the country's positioning in the European conflict, and by Anglo-Irish relations during the I740s.
\end{abstract}

Keywords: Willem van Haren, Dutch Republic, Samuel Boyse, War of the Austrian Succession, Lord Carteret, Ireland, Voltaire

Nowadays literary works by Dutch authors are seldom translated into English. Quite the reverse: the Dutch literary landscape is heavily influenced by British traditions in writing, as best-sellers and more obscure English texts alike become available in Dutch translation. According to Theo Hermans, specialist in the field of Anglo-Dutch translation studies, this strong impact of the English world of letters on the Dutch literary market dates back to the early eighteenth century. Pointing to the significant role played by translations of Joseph Addison and Richard Steele's writings in the launch of a Dutch spectatorial tradition by, among others, Justus van Effen, and addressing the popularity of translations of Sir Walter Scott's historical novels among nineteenth-century Dutch readers, Hermans concludes that '[f]rom the I8th century onwards most of the cultural traffic has been in one direction: from the English speaking world to the Low Countries.' ${ }^{\text {I }}$

However, there are some notable exceptions of early modern Dutch authors whose writings were translated into English. For example, the poem Self-strydt (I620), by the politician and writer Jacob Cats, appeared in John Quarles's English translation as Self-Conflict in I680; and several religious writings by Willem Teellinck, an influential Calvinist during the Dutch Reformation, were translated into English in I620-2I. ${ }^{2}$ This article examines the English translations of several writings by a lesser-known Dutch poet, Willem van Haren (I7IO-I768). Today his work has fallen into oblivion, but in his own time Van Haren was one of the most productive and succesful writers in the Dutch Republic. During the early years of the War of the Austrian Succession (I740-48) several poems and fragments of his work were translated into English and subsequently published in The Gentleman's Magazine (established in I73I), a widely read popular magazine filled with political news, commentary and miscellaneous poetry. Furthermore, an integral translation of Van Haren's Lof der vrede (I742) was published by the Irish poet Samuel Boyse (I708-I749) under the title The Praise of Peace: A Poem in Three Cantos (I742).

(C) (2015) The Authors. Journal for Eighteenth-Century Studies published by John Wiley \& Sons Ltd on behalf of British Society for Eighteenth-Century Studies.

This is an open access article under the terms of the Creative Commons Attribution-NonCommercial-NoDerivs License, which permits use and distribution in any medium, provided the original work is properly cited, the use is non-commercial and no modifications or adaptations are made. 
The existence of so many English translations of Van Haren's work into English raises several questions. What made Van Haren's poems apparently relevant to an English audience in general? Why did Samuel Boyse, an Irish-born writer, decide to translate these poems, and how did he become acquainted with Van Haren's work in the first place? How did he manage to translate texts in a minority language such as Dutch, and how do the English translations relate to the Dutch originals? This article will address these issues by placing Van Haren's work in the context of international European relations, and by demonstrating the centrality of literary translation to Anglo-Dutch relations at that time. In writing his poems, Van Haren's primary agenda was to gain support for Dutch intervention in the War of the Austrian Succession. The great interest in Van Haren's work in England can be clarified by the country's political (re-)positioning in this European conflict, but Boyse's interest in translating Lof der vrede could also be explained in light of Anglo-Irish relations during the I740s. Thus, while the English translations of Van Haren's work have remained virtually unnoticed, they are of interest to both political and literary historians. Furthermore, the English translations of Van Haren's poetry shed light on the complex international networks that were involved in translating a minority language like Dutch during the first half of the eighteenth century.

\section{Poetry and Diplomacy}

There are many examples of early modern European diplomats who at the same time enjoyed reputations as successful poets. In the eighteenth century the English poet Matthew Prior (I664-I72I) was sent as secretary to the English ambassador to The Hague and Paris, and he played an important role in the negotations of the Peace of Ryswick (I697) and the Treaty of Utrecht (I7I3). ${ }^{3}$ His experiences as 'the Englishen heer Secretar' in The Hague would even find their way into his poetry, as becomes clear from 'The Secretary' (I696). ${ }^{4}$ Ambrose Philips (I674-I749) and Charles Hanbury-Williams (I708-I759) were both poets of satirical verse and diplomats. Philips went on diplomatic missions to the Netherlands; ${ }^{5}$ Hanbury-Williams served as the British Ambassador in Dresden between I747 and I75O and as the British envoy at the Russian court during the Seven Years War. ${ }^{6}$

Poetry was often chosen as a means of communication in political issues because of its persuasive function: its rhetorical character made it apt to influence the public's opinion by combining rational argument with emotional appeal. ${ }^{7}$ Despite these evident strong intersections between the world of letters and international politics in the public careers of many Europeans during the eighteenth century, hitherto scholars have primarily considered international relations and cultural history as two unconnected, distinct fields of research. Diplomatic historians usually reconstruct international relations by exploring sources such as official correspondence, treatises and memorials, while cultural and literary historians mainly focus on pamphlets, poems and broadsides. In general, there seems to be little exchange between the two disciplines - a fact that is probably rooted in the assumption that 'real' politics was conducted by a distinguished group of princes and negotiators behind closed doors. As a result, scholars have often overlooked the ways in which poets were instrumental in the realisation of international political decisions and policies or the construction of international political alliances. ${ }^{8}$

More recently, however, a stronger interdisciplinary approach, which emphasises the nexus between international politics and culture, has come into vogue in scholarship on eighteenth-century Europe. In his influential study The Culture of Power and the Power of Culture (2002) Tim Blanning has argued that political and cultural practices were inextricably connected during the period I660-I789. As he contends, the power of princes 
such as Louis XIV and states such as Prussia and Britain was embedded in strong representational cultures, in which artists and poets played a significant role. And vice versa: new political thought and ideas were transmitted by the cultural media to a larger audience, thereby enhancing the 'culture of power'. 9 Similarly, the volume Performances of Peace: Utrecht I7I3 (20I5) foregrounds the function of the cultural media, such as theatrical performances, fireworks, masques and poetry, in the creation of international political relations. The articles in this volume claim that peacemaking was indeed the core business of early modern diplomatic activity, but that policymakers and diplomats also operated within a larger cultural framework. Consequently, their discourse was not only shaped by rules of diplomacy but also influenced by the language, stereotypes and ideas that circulated in popular sources. ${ }^{\text {IO }}$

This article aims to contribute to current trends in eighteenth-century studies which promote an investigation of the interaction between popular culture and international politics as a multi-directional process. The following will demonstrate the role of poetry in the development of international political negotiations during the mid-eighteenth century by a study of the political poetry of Willem van Haren. Born in I7IO in Leeuwarden, the capital of the province of Friesland in the Dutch Republic, and raised in a very well-to-do aristocratic family closely related to the stadtholder's family, Van Haren was appointed deputy of Friesland in the States-General in The Hague in I74O. In this function he was engaged in diplomatic negotations at the highest level. At the same time, he used his literary skills to propagate his political views. Nowadays, Van Haren is mainly remembered for an extensive epic on Friso, one of the (mythological) founding fathers of Friesland, entitled Gevallen van Friso, Koning der Gangariden en Prasiaten (I74I), ${ }^{\mathrm{II}}$ which was inspired by Voltaire's Henriade. ${ }^{\mathrm{I} 2}$ In his own time, however, the Dutch politician was renowned for his shorter political poetry, written during the turbulent years I742-7, as a result of which the States-General decided to augment its troops and to defend the interests of the queen of Hungary and archduchess of Austria, Maria Theresa, during the War of the Austrian Succession. Van Haren was quite pleased with the effect of his political poetry on Dutch policies in the war, judging from a letter he wrote to his nephew: 'J'ai fait lever 20,000 hommes par trois pièces de vers.' ${ }^{\text {I3 }}$ Furthermore, Van Haren's poetical works played a major role in cementing Anglo-Dutch relations during this period of upheaval.

\section{Van Haren's Poetry and the War of the Austrian Succession}

When Charles VI died in $1740,{ }^{\mathrm{I}} 4$ and war broke out over the question of his succession, the Dutch Republic initially refrained from direct involvement in warfare, officially persisting in a policy of neutrality until France's invasion of the Austrian Netherlands in $1744 .^{\text {I5 }}$ This neutral position - which implied a violation of the Pragmatic Sanction that had been signed by the Dutch Republic in I7I3 and which, on a national level, was inspired by fear that William IV of Orange would be appointed as captain-general and stadtholder of all districts in the Republic ${ }^{\mathrm{I} 6}$ - increasingly became the subject of international critique. This becomes, for instance, clear from the cartoon 'The Benefits of Neutrality' (I742), which suggests that the Dutch obtain economic advantage by staying out of the large-scale European conflict:

Ambitious France and haughty Spain

Unite the Hornes of Pow'r to gain

Against them England drags the Tail

While the sly Dutchman fills his Pail. ${ }^{\mathrm{I} 7}$ 
Within the Dutch Republic, Deputy Willem van Haren was not only one of the staunchest supporters of Willem IV of Orange but also one of the main defenders of the Pragmatic Sanction. He not only voiced his sympathy for the Hungarian queen's cause in the States-General, endeavouring to have an army raised in her defence; he also attempted to rally political support in general for the Habsburg heiress through his poetry, which responded to the conflicts in Europe ${ }^{18}$ In the context of the War of the Austrian Succession, five of his poems are of particular importance: Leonidas (I742), Lof der vrede (I742), Aan de koninginne van Hongaryen (I742), Aan de Groot-Brittanische Natie (I742) and Aan zyne Groot-Brittannische Majesteyt (I743).

In February I742 Van Haren came to the attention of the public with Leonidas, which renders the heroic speech of the Spartan king Leonidas to his people. Leonidas incites his subjects to show their usual courage and to join his fight against the Persian king Xerxes, who, driven by 'Heerschzugt', I9 ruthless ambition and thirst for power, is swiftly conquering Greek territories. ${ }^{20}$ Van Haren's poem was influenced by Richard Glover's Leonidas (I737), in which the Spartan king epitomises the author's views of the ideal ruler who is a 'patriot' obeying the call of his country and people to secure their 'justice, glory and liberty'. ${ }^{2}$ Underscoring Glover's conception of ideal rulership, Van Haren wrote his poem to express his affiliation with the Orangeists who wished to see Stadtholder Willem IV as captain-general of the Dutch Republic and the Orange dynasty restored to power. ${ }^{22}$ However, Van Haren's Leonidas also reflected on the ongoing War of the Austrian Succession: Leonidas's urge to stop the 'snode Dwing'landy' ${ }^{23}$ - that is, the usurping military power of Xerxes - and thereby to secure the liberty of the people on the Greek isles could be interpreted as a plea for military action against especially Prussia, which had previously occupied Silesia, and France, which had previously invaded Bohemia and which now had plans to take Germany. ${ }^{24}$

That Van Haren's poem was indeed read as a plea for giving up neutrality by offering military and political assistance to Maria Theresa is clear from the great stir that it caused, both nationally and internationally. As several sources claim, in the Dutch Republic well over I00,000 copies of Leonidas were sold within three days, a number that indicates the immense popularity of the text. ${ }^{25}$ Reportedly, Leonidas was recited on bridges and public places in Amsterdam, its publication led to an endless stream of reactions for and against Van Haren $^{26}$ and, according to a contemporary politician, it was 'almost got by heart by the mobb - [so] that the Magistrates dreaded the consequence'. ${ }^{27}$ Although the public impact of Leonidas in the Dutch Republic may be connected to its Orangeist agenda, the written responses to Leonidas reveal that the poem was mainly interpreted in light of the positioning of the Dutch Republic in the European war. This becomes evident from poetic replies such as 'Gezang aan het Vereenigde Nederland' ('Song to the United Netherlands'), which praises the former loyalty of the Dutch Republic to Charles VI, ${ }^{28}$ and Rudolf Agricola's 'Rhytimologia Belgica in Augustam Vindobonam', which calls for support to Maria Theresa. ${ }^{29}$

Furthermore, the controversy that translated versions of the poem provoked abroad shows that its bearing on the War of the Austrian Succession was generally observed. Translations of Leonidas into Latin, French and English were produced soon after its first Dutch publication, ${ }^{30}$ and the French prose translation put the Dutch ambassor in Paris, Abraham Van Hoey, in an embarrassing position. In line with the Dutch policies of neutrality, Van Hoey believed that the Dutch Republic should remain on good terms with France and avoid war with that nation at any cost. However, Van Haren's poem raised animosities between France and the Dutch Republic through its implicit critique of France's aggressive warfare. Rumour had it that copies of Leonidas were 'flying' all 
over Paris. ${ }^{3 \mathrm{I}}$ The position of the Dutch ambassador was seriously compromised when the French ambassador in The Hague, Marquis de Fenélon, sent copies of the poem and a French translation to his foreign secretary and King Louis XV himself. ${ }^{32}$ Hearing about the poem, written, notably, by a deputy of the States-General, Van Hoey was called to account by French minister Jean Jacques Amelot, and barely knew how to pacify the indignant official. ${ }^{33}$

Van Haren's Leonidas provides an example of the ways in which poetry can be a tool leading to concrete political action in connection to international affairs: one month after its publication, in March I742, the Dutch Republic decided to augment its troops, ${ }^{34}$ which were to protect the eastern borders of the Republic against the possible threat of invasion by French and Prussian troops. Leonidas thus did not signify a real intervention in the Dutch Republic's international relations. However, it can be argued that the other poems that Van Haren wrote in I742 and in early I743 probably contributed to the new policies adopted by the States-General on 22 June I743, when 20,000 Dutch soldiers were sent to Austria to fight for the Habsburg queen's cause. ${ }^{35}$

One of these influential texts was the long mythological poem Lof der vrede (I742). In this text Van Haren engages with the call against intervention in the war and in favour of peace that dominated public discourses in the Dutch Republic. Lof der vrede makes a distinction between 'valsche Vrede' (false security), on the one hand, and 'opregte Vrede' (true peace), on the other. ${ }^{36}$ Reflecting Lutheran ideas about the differences between securitas, associated with carelessness and false hope, and certitudo, identified with sincere faith in God, ${ }^{37}$ the poem suggests that false security is often created by tyrants and monarchs like Julius Caesar, who seduce the people with false promises that are rooted in self-interest and who engender internal strife, 'Tweedragt'. ${ }^{38}$ The poem can be read as a warning against blind ambition and betrayal by princes - resonating with biblical passages such as Psalm I46, in which true belief in God is praised and false faith in princes rejected. ${ }^{39}$ By contrast, true peace can only be achieved by governments in commonwealth states that have the well-being of the people at heart, ${ }^{40}$ and the poem thus bears witness to Van Haren's support of the stadtholder and Orangeism. At the same time, Lof der vrede voices criticism of the non-interventionist politics of pro-French and anti-Orangeist members of the States-General that lull the republic into a slumber of false security. As the poem states, those who have been appointed by the people as their representatives are mainly concerned with their monetary interests and, as a result repress any consciousness of the potential danger of foreign invasion. ${ }^{4 \mathrm{I}}$ While these statesmen hold the country hostage by 'valsche Rust', a false sense of tranquility and unassailability - symbolised by Morpheus, the god of sleep - its autonomy is unprotected against foreign attacks by 'Dwinglandye en 't vuur des Oorlogs': that is, warfaring, usurping tyrants. ${ }^{42}$ Lof der vrede thus implicitly pleads for military fortification of the Republic and for active involvement in the war as a way to put a stop to the conquests of powers such as France which do no not respect the freedom of other nations.

Van Haren's Aan de koninginne van Hongaryen, dedicated to Maria Theresa and also published in $1742,{ }^{43}$ praises the queen's steadfast bravery in the face of military aggression, as she would rather choose death over 'schande en schaâ', the dishonour of defeat. ${ }^{4}$ At the same time the poem condemns the powers that are disloyal to the Pragmatic Sanction, questioning Maria Theresa's right to the throne and plunging Europe into a bloody war. Van Haren's ode to Maria Theresa seems to have been published around the same time that Voltaire wrote his poem in praise of the queen, 'Ode faite le 30 Juin I742; Par Mr. De Voltaire a la louange de la reine de Hongrie’, on 30 
June I742. The question is: was one of the authors influenced by the other? This is not unlikely, because of the references in both poems to the queen's great qualities and the bloodshed in Europe. What is more, the two men of letters were well acquainted with each other's work. Voltaire honoured the Dutch poet with an ode on his poetry, expressing his admiration for his audacity in the pursuit of liberty: 'mais j'aime ton courage/ Né pour la Liberté, tu penses en heros.' ${ }^{45}$ It is assumed that Voltaire, while voicing sincere admiration for the Dutch poet, intended to win Van Haren over to a different perspective on France's position in the European succession conflict. ${ }^{46}$ The international political dialogue that appears to exist between Van Haren's Aan de koninginne Van Hongaryen and Voltaire's poem demonstrates the function of Van Haren's oeuvre in the negotiation of international politics, both within the Republic and across its borders.

\section{Van Haren's Poems and Anglo-Dutch Relations}

That Van Haren also sought support for his political views in elite circles outside the Duch Republic is revealed by the two odes he wrote in praise of the new political directions towards the War of the Austrian Succession that Britain had taken: Aan de Groot-Brittanische Natie (I742) and Aan zyne Groot-Brittannische Majesteit (I743). In February I742 a significant regime change had taken place in Britain: after the elections of the summer of I74I had already reduced his parliamentary majority, Robert Walpole fell from office after two decades of Whig supremacy. With regard to the War of the Austrian Succession, Walpole's government had 'resisted calls for beligerence to the end', convinced that peaceful relations with France would guarantee Britain's commercial prosperity. ${ }^{47}$ By contrast, his successor as chief minister, Lord Carteret, the second earl of Granville, aimed to end Britain's policies of neutrality, partially driven by the ambition to strengthen Britain's imperial hold over Hanover. ${ }^{4}$ Carteret increased the pressure to send troops to defend the queen's rights, and, as a result, in June I742 Britain sent I6,000 soldiers across the sea, with the mission to support Maria Theresa's socalled 'Pragmatic Army'. ${ }^{49}$ In Aan de Groot-Brittanische Natie Van Haren commends the 'Grootmoedig Volk', the brave people of Britain, for entering the war in order to respect their covenant with the house of Habsburg: 'Dat nakoomt wat gy hebt beloofd' (to do as you have promised). Van Haren thus eulogises Britain's opposition to the 'yzeren Staf der Dwingelandy', the iron rod of oppression that threatens Europe. Simultaneously, the poem implicitly criticises the Dutch Republic's cowardly investment in selfinterest, which entails a breach of loyalty: 'Waar LAFHEID en waar EIGEN VOORDEEL,/ De HEIL'GE TROUW bezwyken doed' (where cowardness and own benefits breaks down loyalty). ${ }^{50}$

Van Haren's ode to the British nation on its intervention in the War of the Austrian Succession may partially be explained through his personal affiliations with the house of Hanover. In I737 Van Haren had married Marianne Charles, lady-in-waiting to Princess Anne, who herself was the spouse of the Frisian stadtholder Willem IV and the eldest daughter of the later King George II of Great Britain. Although at the time Princess Anne had objected to the marriage, Van Haren's connections with Willem IV facilitated his access to British royal circles. At the same time, Aan zyne Groot-Brittannische Majesteit shows that Van Haren used his poetry to reach out consciously to political allies throughout Europe as a way to influence Dutch politics. That Van Haren intended to solidify the political ties between Britain and the Dutch Republic, as nations that were to join forces in 
the cause of Maria Theresa, is moreover illustrated by his Aan zyne Groot-Brittannische Majesteit. In this ode, written at the time when the Dutch Republic had first sent troops to the aid of the Habsburg pretender, George II is extensively praised for his victory at the battle of Dettingen, not having been detained in his courage by any "aardsche Grootheid' - that is, earthly power or quest for wealth..$^{\text {I }}$ During this battle on 27 June I743, the British army, led by King George, defeated the French.

Van Haren must have written the poem with the diplomatic agenda of cementing Anglo-Dutch relations in mind. He sent a copy of his poem to Lord Carteret, along with a letter extolling King George's 'Actions Héroiques' and calling him 'le magnamine Liberateur de l'Europe', requesting that Carteret deliver the ode to His Majesty. Shortly afterwards, Van Haren received a response from Carteret, informing him that the monarch had been very pleased with the poem. Carteret added that he did not understand Dutch, but was assured that the right emotions had been expressed after reading a translation by 'Monsieur Trevor'52 - that is, Robert Hampden Trevor (I706-I783), who had been appointed head of the British embassy in the Dutch Republic in I739.

\section{Van Haren's Poems in English Translation}

Aan zyne Groot-Brittannische Majesteit was by no means the first political poem by Willem van Haren that had been translated into English. In fact, all of Van Haren's poems that dealt with the War of the Austrian Succession were made available to British audiences. Shortly after Leonidas was published, an English translation of one specific part of the poem, Leonidas's speech to his people, appeared in the March issue of The Gentleman's Magazine as 'The Character and Part of the Speech of Leonidas, from the Dutch of M. Van Haaren'. ${ }^{53}$ The translation was published anonymously, but its author was probably the Irish poet Samuel Boyse. Boyse had previously contributed various verses to the magazine under the signature of ' $Y$ ' or 'Alceus', such as 'An ode sacred to the Birth of the Marquis of Tavistock', which appeared in The Gentleman's Magazine of February 1740. ${ }^{54}$ Boyse also translated the other poems by Van Haren that expressed support for intervention in the interest of Maria Theresa. Translated extracts from Lof der vrede were published in The Gentleman's Magazine in May 1742, ${ }^{55}$ and Boyse also published a translation of the entire text in a separate edition.

Subsequently, Boyse tried his hand at Van Haren's ode on Maria Theresa. His English translation did not appear in The Gentleman's Magazine until December I742, but Boyse had already announced this future project in the issue of July I742. There a poem by Boyse himself, in which he responded to an ode by Voltaire about the queen of Hungary, was printed. This 'Ode addressed to M. Voltaire, ocassioned by his Ode in praise of the Queen of Hungary', accuses Voltaire of glorifying his own nation instead of singing the praises of the Hungarian monarch. Boyse writes that he is 'greatly disappointed' by Voltaire's poem, which, instead of describing the 'glorious character of that august princess', merely provides 'a wild panegyrick on his own nation and some well-turned compliments to Cardinal Fleury'. Urging that Voltaire forbear 'to talk of French renown', Boyse claims that 'I may perhaps next month trouble you with a poem that will do more justice to her Hungarian majesty.' Boyse's poetic response to Voltaire explicitly refers to Van Haren and the British delegate in The Hague, Lord Stair: And when I praise Van Haren's name,/ Or speak of Stair's eternal fame/ Believe me understood. ${ }^{56}$ This allusion suggests that the poem that Boyse promises to his readers is indeed the translation of Van Haren's ode to the Habsburg heiress, an impression that is moreover 
confirmed by the fact that on the very same page a translation of Van Haren's Aan de Groot-Brittannische Natie is printed: 'Ode in praise of the British Nation, from the Dutch of Van Haren'. ${ }^{7}$

The translation of Van Haren's ode to Britain is signed by 'Phylargyrus', a pseudonym that is generally assumed to have been adopted by the English curate of St Faith's Church, in London, William Rider, ${ }^{5}$ who enjoyed some moderate successes as a writer of poetry, history and lexicography and as the translator of Voltaire's Candide (I759). ${ }^{59}$ It seems, however, unlikely that Rider was the author of the first English version of Aan de Groot-Brittannische Natie. The issue for May I743 once again publishes an English translation of Van Haren's poem, also authored by 'Phylargyrus', stating, however, that 'a translation of this ode, by another hand, was inserted before (See vol. XII, p. 383)', but which had displeased the Dutch poet for the 'mistakes as to Mr Van Haren's meaning'. ${ }^{60}$ The phrase 'by another hand' evokes the suggestion that the second translation, which followed the Dutch original more closely, was by a different author, and that the first translation may have been unjustly assigned to 'Phylargyrus'. In fact, it appears more probable that Boyse had made the first, disapproved, translation, for in a letter of July I742 to the Gentleman's Magazine's editor, Edward Cave, Boyse contends: 'The ode to the British Nation I hope to have done to-day. ${ }^{61}$ The trauma of having his translation of Van Haren's Aan de Groot-Brittannische Natie replaced by a new version by, probably, William Rider, appears to have affected Boyse's later contribution to The Gentleman's Magazine. Supplying a translation of Van Haren's ode to George II that was published in the periodical in June $1743,{ }^{62}$ Boyse added a verse in which he responded very critically to a poem on virtue by 'Phylargyrus' in an earlier issue. ${ }^{63}$

The controversy over the deficiencies in the first English version of Aan de Groot-Brittannische Natie points to the complexities of translating a minority language. Born in Ireland in 1708 as the only son of Revd Joseph Boyse, and having taken up his studies at the University of Glasgow at the age of eighteen, Samuel Boyse's skills probably did not include any profound knowledge of Dutch. ${ }^{64}$ Neither do biographies of his rival translator, William Rider, provide any evidence that he possessed a thorough command of the Dutch language. So how did these two authors manage to translate Van Haren's poetry into English, if neither of them was at all proficient in Dutch? Based on extant sources and a reconstruction of the international infrastructures in which Van Haren's texts circulated, one may argue that Boyse and Rider primarily made use of prose translations of Van Haren's poetry in English and French. In The Gentleman's Magazine of May I743 the editor observes that the improved translation of Aan de Groot-Brittannische Natie by 'Phylargyrus' was completed with the aid of 'a literal prose translation in English from the original low Dutch' made by 'that polite and ingeneous author' Willem van Haren himself. ${ }^{65}$ Being married to a woman of English descent, it is likely that Van Haren had some basic knowledge of English, which enabled him to intervene with the reproduction of his poem in English.

The editor's note in this issue of The Gentleman's Magazine of May I743 at the same time creates the impression that Samuel Boyse had apparently made use of a French translation of Van Haren's ode to the British nation, contending that this first translation 'was very well received in Holland, tho' done from the French'. ${ }^{6}$ A French translation of Van Haren's ode to Britain was published in $1742,{ }^{67}$ so it is not improbable that Boyse based his 'Ode in Praise of the British Nation' partially on this French translation of the original text. In his own days Boyse was well known as 
a translator from French: in I730 he moved to Edinburgh, where he published his first volume of poems, Translations and Poems Written on Several Subjects, which included a translation of an ode by the French poet François de Salignac de la Mothe-Fénelon. During the I740s Boyse apparently took on many commissioned translations, including pamphlets by Voltaire and Fénelon's Traité de l'existence de Dieu (1713), driven by want and penury. ${ }^{68}$ In a letter dating from July I74I, Boyse wrote that he was employed 'all last summer' by Mr Cave 'in French translation, a province highly agreeable to me, and the most profitable business stirring'. ${ }^{69}$

The impression that Boyse may have worked on his English versions of Van Haren's Dutch poems through access to French translations is further supported by the translations themselves. His translation of Leonidas, for instance, seems to be based, at least partly, on the French translation in prose, which was available in print at that time..$^{70}$ Boyse invariably uses the word 'go' in Leonidas's long speech, as an imperative to send away all those who do not dare to join him in his fight against Xerxes: 'But go! unworthy of your spotless race/ Degenerate, go - and court your own disgrace. ${ }^{7 \mathrm{I}}$ The French translation uses the expression 'Allez si vous voulez', which corresponds with Boyse's choice of vocabulary, but the Dutch original by Van Haren makes no mention of an equivalent expression by Leonidas. At other moments, however, Boyse stays closer to the Dutch original than the French version - for instance, when he refers to an 'honest weapon' by which Leonidas is willing to kill himself. ${ }^{72}$ By comparison: in Van Haren's poem, the Dutch expression 'Oorlogs-Zwaard' is used, ${ }^{73}$ while the French translation does not mention any weapon at all. ${ }^{74}$ In other words, Boyse's translation appears to mainly inspired by the French translation, but it also appears evident that he had looked closely at the Dutch original and had managed to grasp its subtleties.

Other translations by Boyse of Van Haren's work could more appropriately be defined as free rather than literal translations, for he frequently took great liberty with Van Haren's texts. This becomes evident from Boyse's The Praise of Peace. Boyse appears to have deliberately left out parts of the original that would sit uneasily with British politics, such as the passage in which Van Haren condemns monarchy as a form of government. ${ }^{75}$ Whereas Van Haren's poem more implicitly justifies an interpretation of the text against the background of the neutrality of the Dutch Republic, Boyse included extensive notes to identify the concrete events and political contexts that the poem more implicitly comments on: 'The Assurances of France, to draw the States into the proposed Neutrality' and 'The Intrigues of the French Ambassador, the M. of Fenelon, at the Hague', are just two examples. ${ }^{76} \mathrm{He}$ also added verses that cannot be found in the original text, such as the following celebration of the Dutch past:

Or godlike Nassau on the Verge of Fate,

Another Scipio rose to save the State,

Names dear alike to Liberty and Fame,

Whose lasting Virtues endless Honours claim. ${ }^{77}$

This passage is accompanied by four endnotes, in which Boyse states, in very favourable terms, who the mentioned persons were and what part they played in Dutch history. The prince of Orange, for instance, 'greatly defended his Country for the Spaniards', while William III 'saved his Country on the Brink of Ruin in I672' and when he became king of England 'in I688 rescu'd Britain from the Danger of arbitrary Power' ${ }^{78}$ 
The most striking change that Boyse made concerns the ending of the poem. Lof der vrede ends with a warning of divine revenge, expressing an apocalyptic vision of thunder, lightning and an avalanche that will make the earth tremble with fear: 'The lightning strikes again and again; And makes the snow melt that was laying for a long time on the highest mountains; the immense noise makes the earth tremble. ${ }^{79}$ By contrast, Boyse depicts a joyful scene, set in spring, which is imbued with hope of peacefulness and promises of regeneration: 'So when the April Show'r with balmy Dews,/ The Spring awakens, and the Earth renews [...] Majestic Nature shows her beautous Face,/ And wafts around the Joys of heavenly Peace! ${ }^{80}$ Apparently, Boyse aimed to present a more optimistic perspective on the succession crisis, hinting that an effective response to the powers of usurpation would lead to a stabler, more harmonious New Europe.

\section{The Politics of Boyse's Translations}

Some of the drastic revisions that Boyse made to Van Haren's original poems can be attributed to his limited understanding of Dutch, but Boyse also consciously intervened with Van Haren's poetry by adding commentary that emphasised its relationship to current international affairs and by adding verses that promulgated pro-Orangeist views. In some cases the additions and diversions are so numerous that it is perhaps more apt to speak of adaptations than translations. The question arises why Boyse took the trouble to make Van Haren's writings available in English in the first place. What were his personal or political motivations in providing these translations?

In order to answer this question, it is certainly helpful to examine biographical accounts of Boyse's life. As these reveal, Boyse was in a permanent state of pecuniary want, caused by an unfavourable marriage, drinking problems and immoral behaviour. $^{8 \mathrm{I}}$ When he went to London in I737 to try his fortune there, he initially achieved some success through his original poetry: The Olive (I737), which was dedicated to Sir Robert Walpole and 'procured him a present of ten guineas', and The Deity (I739). ${ }^{82}$ However, his intemperate habits and his failure to meet the deadlines for commissions led him into continuous debts, and in I740 he was reduced to such 'extremity of human wretchedness' that he had to pawn all his clothes, having 'not a shirt, a coat, or any kind of apparel to put on'. ${ }^{83}$ Totally 'unfit to support himself in the world', ${ }_{4}$ Boyse often appealed to acquaintances in his permanent state of distress and would write for several journals, such as The Gentleman's Magazine.

Translating and writing poetry was, therefore, primarily a means to secure an income for Boyse. In light of this, it seems likely that, as an author and translator, Boyse was driven not by any personal political sympathies or convictions but mainly by his necessities. Boyse's translations of Van Haren's poetry may have been inspired by a sincere admiration for the Dutch poet's literary skills or by political affinities, but the ideas they evoked were also very compatible with the politics of The Gentleman's Magazine, Boyse's most permanent employer. A close investigation of issues of The Gentleman's Magazine for I742 reveals that the periodical promoted support for Maria Theresa during the War of the Austrian Succession. The January issue of that year reprinted an essay that had earlier appeared in The Craftsman of 2 January, 'A Political Sermon on the Commencement of the New Year', which called for Britain's involvement in the war and its allegiance to the Pragmatic Sanction. Expressing serious concern about the current state of 'foreign Affairs, which seem to threaten no less than the Overthrow of the Balance of Power in Europe', and specifically 'the sudden and unprecedented March 
of the French Troops into the Heart of Germany', the anonymous author calls for British intervention and loyalty to 'her Hungarian Majesty and the Whole house of Austria': 'But what Person or Persons, by their Tameness, Inactivity or Treachery, are properly answerable for giving the French Court such an Opportunity of dictating laws to all Europe, is a Point, which deserves the strictes Inquisition. ${ }^{85}$

In a similar vein a letter that had earlier appeared in The Craftsman of 3 April I742, and which was reprinted in the April issue of The Gentleman's Magazine, voices strong disapproval of Britain's breach of earlier agreements with the house of Habsburg in favour of its relations with Hanover: 'the House of Austria had been preserved from Destruction' if the London government 'had not run into the Treaty of Hanover, and such unnatural Treaties and Negotiations, but steadily persevered in the antient Alliance'. ${ }^{86}$ In light of The Gentleman's Magazine pro-interventionist viewpoint with regard to the War of the Austrian Succession, it is understandable that Boyse was encouraged to translate Van Haren's poems for the periodical that financially supported him.

The politics of the magazine were in tune with the policies that were to be adopted by the belligerent Lord Carteret, and, interestingly, Boyse had dedicated a poem to this second earl of Granville in I725, on Carteret's appointment as lord-lieutenant of Ireland. The preceding years had been marked by grave tensions in Anglo-Irish relations: in I722 the House of Commons had prepared a bill 'for raising one hundred thousand pounds a year, upon the real and personal estates of all papists, or persons educated in the popish religion' as a way to curb Catholicism in Ireland. The bill, which was 'stamped with the royal sanction', was, however, rejected by the House of Lords. ${ }^{87}$ The years I722-5 further saw fierce resistance against the London government's attempts to have its policies implemented in Ireland. A serious crisis arose over the patent granted to the English ironmonger William Wood, who was to supply new halfpennies and farthings worth just over $£$ IOO,OOO, because of a shortage of coins in Ireland. Many Irish refused to use the new coins after Jonathan Swift had suggested in Drapier's Letters (I724-5) that they were of inferior mint. ${ }^{88}$ Walpole had lost all his faith in the reigning viceroy, the Irish duke of Grafton, and adopted a line of appointing Englishmen in key positions. As a result, Carteret was sent to Ireland in October 1724 , in order to counteract the rebellion against the halfpennies, among other things. 89

In 'To the Right Honourable, The Lord Carteret, on his first Arrival in Ireland, Anno I725', Boyse beseeches Carteret to show compassion with Ireland. Ireland, as the poem states, is a 'sinking Land' both economically and politically, especially because Britain fails to show maternal care to the Anglo-Irish classes that 'claim' their 'descent' from Britain: 'How would her Sons, still zealous for her cause/ Assert her Empire and maintain her Laws?' The poem expresses the hope that Carteret, as the new lord-lieutenant, will protect Ireland's welfare just as William III had previously rescued Hibernia: 'That Land immortal Nassau saved before' ${ }^{\circ}$ Boyse's poem is clearly imbued with an Orangeist political discourse: it employs an imperial rhetoric by requesting support from what the descendants of the English and Scottish colonisers, the Anglo-Irish, would consider as their mother country, Britain. The poem additionally refers to the regime of William III of Orange, who had successfully defeated the Jacobite forces in the battle of the Boyne in I69o, and who had brought Protestant settlers from Britain to colonise the land. ${ }^{9 \mathrm{I}}$ Boyse's Orangeist affiliations are also underscored by the poems on the War of the Austrian Succession that he translated or wrote himself, for these champion the reign of William III. As 
was mentioned previously, Boyse's The Praise of Peace contains a footnote that praises William III as the ruler who 'in I688 rescu'd Britain from the Danger of arbitrary Power' of James II's reign. ${ }^{92}$ Furthermore, in the verses that Boyse himself composed to celebrate George II's triumph at the battle of Dettingen, 'Albion's Triumph', Boyse once again explicitly refers to William III as one of the leading figures of both British and European history: 'Aspire like Nassau the glorious Strife/ Keep thy great Sire's examples full in Eye.'

While 'Albion's Triumph' does not relate to Boyse's native Ireland in any respect, it nevertheless remains interesting that this poem also mentions Carteret, whom Boyse had almost two decades earlier heralded as a possible harbinger of peace in the context of Ireland and who was the chief minister at the time, as a figure whose prointerventionist solidity might contribute to the establishment of peace in Europe at large: 'Carteret, thou the column of the state!'93 Obviously, Carteret's support of armed assistance to Maria Theresa could count on the approval of Boyse and his readers in The Gentleman's Magazine; but in Ireland's recent past Carteret had indeed also proved to be the stronghold that had brought relative prosperity and peacefulness to Ireland, and which had moreover made a strong case for the position of the Protestant Anglo-Irish classes. Shortly after his instalment, Carteret not only managed to have the patent of the much detested Wood's halfpennies withdrawn, thereby ending the controversy that had severely strained Anglo-Irish relations. He was also known for having

by a mild and moderate government, made the Irish happy and contented; he checked and restrained the most designing and artful part of the nation, and soothed the most violent. He controlled prodigality, and encouraged industry. ${ }^{94}$

While trying to smooth differences between Britain and Ireland as well as within Ireland - a nation otherwise strongly divided by ethnic and religious sectarianism-Carteret additionally bore the interests of the Protestant ascendancy in mind. When, in I729, the rights of Ulster Presbyterians were to be further restricted through a Test Act, and a great emigration of this group to North America was at hand, Carteret wrote to London to express his concern that the position of Protestants, both in the region and in the country at large, threatened to become weaker.95

In light of Carteret's reputation as a conciliator of differences between Britain and Ireland, it becomes tempting to read Boyse's The Praise of Peace not only through the lens of the contemporary Austrian War of the Succession but also as an implicit comment on the state of affairs in Ireland. Could we indeed view the warning against inattentiveness to threats to a nation's peace as a (renewed) appeal to Carteret to consider peacefulness with regard to Anglo-Irish relations in his new position? The fact is that when Robert Walpole left office in February I742, the situation within Ireland was far from stable or peaceful. Although no major crisis had taken place since the cabals over Wood's halfpennies, rivalries between the undertakers of Ireland, such as Henry Boyle and John Ponsonby, Lord Bessborough, made the country more vulnerable to internal strife and patriot agitations. ${ }^{96}$ Peace in the Irish colony was also fragile, as the country had been hit very badly by a famine during the cold winter of $1740-4 \mathrm{I}$, culminating in food riots in April and May I74I. ${ }^{97} \mathrm{~A}$ reading of Boyse's The Praise of Peace against the background of Ireland's state of affairs remains speculative, but further ground to legitimise such a perspective may be found in the interconnection between Irish patriotism and the Austrian War of the Succession. In 
preceding years many Irish peasants - often with Jacobite sympathies - had emigrated to France in order to find better living conditions and to support the Stuart claim to the British throne. Forming distinct Irish regiments in France that consisted of emigrated Irishmen or 'sons of Irishmen in France', the 'Irish Brigade as a single unit' was attached to the French army and became actively involved in the warfare over the Austrian succession in I74I.$^{98}$ Although it is difficult to establish whether Boyse had this Irish, Jacobite contribution to the European war in mind when he translated Van Haren's Lof der vrede, a consideration of the ways in which this translation may also have evoked Anglo-Irish issues is significant.

\section{Conclusion}

This study of Willem van Haren's poetry and Samuel Boyse's translations has shown that in the eighteenth century the worlds of diplomacy and poetry were inextricably interconnected, as they reveal the centrality of literary translation to Anglo-Dutch relations during that time. Van Haren used his literary skills to tighten his personal and political bonds with Britain and to gain support for his political views. The success he attained in doing so may partly be attributed to the English translations of his work by Boyse: The Gentleman's Magazine became an important medium which spread Van Haren's ideas overseas. However, Boyse also adapted Van Haren's texts, in order to make them a mouthpiece for Orangeist ideologies, and - above all - a reflection of the political affiiations of his readers. Thus Van Haren's Dutch poems may have become applicable to specific international, European situations, including perhaps Anglo-Irish relations.

The close relationship between diplomacy and cultural media requires further exploration: is this case unique, or did poetry play a role in the early modern world of international diplomacy more often? To what extent did discussions in the public media have an effect in diplomatic circles? How did those involved in political negotiations, in turn, make use of the media to gain support for their views? One of the advantages of using poetry as a diplomatic tool was, besides its persuasive and rhetorical function, its established pedagogical function: as Samuel Johnson wrote, 'the end of poetry is to instruct by pleasing.' 99 This prevalent assumption that poetry could inspire moral enlightenment may explain the enduring significance of The Praise of Peace during the War of the Austrian Succession, especially when the peace negotiations started in Aachen. Extracts of the poems were published once again in The Gentleman's Magazine, at the request of one of its readers. According to this person, Van Haren's poem would 'give a taste of such sentiments as are worthy the perusal of every honest Briton, who wishes well to the cause of liberty, and hopes for an honourable and lasting peace'. ${ }^{\text {Ioo }}$

\section{NOTES}

I. Theo Hermans, 'Dutch Literary Translation into English', in Olive Classe (ed.), Encyclopedia of Literary Translation into English (Chicago, IL, and London: Fitzroy Dearborn, 2000), p.39I. We are grateful to The Netherlands Organisation for Scientific Research (NWO), for funding part of the research that lies at the basis of this article, through the VIDI project Proud to be Dutch; The Role of War and Propaganda Literature in the Shaping of an Early Modern Dutch Identity (I648-I8I5), and for funding its publication through open access.

2. See Hermans, 'Dutch Literary Translation', p.39I. 
3. See Leopold George Wickham Legg, Matthew Prior: A Study of His Public Career and Correspondence (Cambridge: Cambridge University Press, [I92I] 20IO).

4. The Poems of Matthew Prior, vol. II (London: C. Whittingham, I822), p.I34.

5. See Irvin Ehrenpreis, Swift: The Man, His Works and the Age, vol. II, Dr. Swift (Cambridge, MA: Harvard University Press, I983), p.243.

6. See David B. Horn, Sir Charles Hanbury Williams and European Diplomacy, I747-58 (London: Harrap, I930).

7. See, for example, Jan Bloemendal and Arjan van Dixhoorn, 'Literary Cultures and Public Opinion in the Low Countries', in Jan Bloemendal, Arjan van Dixhoorn and Elsa Strietman (eds), Literary Cultures and Public Opinion in the Low Countries, I45O-I65O (Leiden: Brill, 20II), p.I-35.

8. Examples of studies in the field of early modern European relations that overlook this significant function of poetry are Lucien Bély and Isabelle Richefort (eds), L'Europe des traités de Westphalie: esprit de la diplomatie et diplomatie de l'esprit (Paris: Presses Universitaires de France, 2000), and Jeremy Black, European International Relations I648-I8I5 (New York: Palgrave, 2002).

9. Tim Blanning, The Power of Culture and the Culture of Power: Old Regime Europe, I660-I789 (Oxford: Oxford University Press, 2002). See also Kathleen Wilson, The Sense of the People: Politics, Culture and Imperialism in England, I7I5-I785 (Cambridge: Cambridge University Press, I995).

Io. See Renger de Bruin et al. (eds), Performances of Peace: Utrecht I7I3 (forthcoming).

II. This biographical information is based on J. van Vloten, Leven en werken Van W. en O.Z. van Haren, Friesche edellui (Deventer: A. ter Gunne, I874), and J. Prinsen, 'Willem van Haren', in C. Molhuysen and P. J. Blok (eds), Nieuw Nederlandsch biografisch woordenboek, vol. VIII (Leiden: A. W. Sijthoff, 1930), p.689-93.

I2. See Jan te Winkel, De ontwikkelingsgang der Nederlandsche letterkunde V: Geschiedenis der Nederlandsche letterkunde van de Republiek der Vereenigde Nederlanden (Haarlem: De erven F. Bohn, I924), p.353.

I3. Willem van Haren to Oene Van Grovestins, I5 April I756, cited in J. H. Halbertsma, Het geslacht der Van Haren's (Deventer: J. de Lange, I829), p.303.

I4. Charles VI had tried to secure the rights of his daughter on the Habsburg throne through the Pragmatic Sanction of I7I3, but her position was challenged immediately after his death. See M. S. Anderson, The War of the Austrian Succession, I74O-I748 (London: Routledge, 2013), p.8, and Reed Browning, The War of the Austrian Succession, I74O-I748 (New York: St Martin's Press, I995), p.I8.

I5. See Christopher Duffy, Military Experience in the Age of Reason (London: Routledge, 2005), p.22.

I6. See A. Nienes and Marijke Bruggeman (eds), Archieven van de Friese Stadhouders (Hilversum: Verloren, 2002), p.4I-2.

I7. Anon., The Benefits of Neutrality (London: C. Goodwin, I742).

I8. See te Winkel, De ontwikkelingsgang, p.357.

I9. Willem van Haren, Leonidas, in Derde vervolg der gedichten, of vierde stuk, der uitmuntende gedigten, Van voor, en tegen jonkheer Willem van Haren (Amsterdam: A. Olofsen, I742), p.9.

20. See Van Haren, Leonidas, p.8.

2I. Richard Glover, Leonidas: A Poem, I737 (London: T. Cadell, I770), p.I7, 2I . For a comparison between Glover's and Van Haren's poem, see Ian Macgregor Morris and Uta Degner, 'Evénements de Circonstance: The Classical Tradition in the Age of Revolution', in Maike Oergel (ed.), (Re-)Writing the Radical: Enlightenment, Revolution and Cultural Transfer in I79os Germany, Britain and France, (Berlin: Walter de Gruyter, 2012), p.I88-9I .

22. See te Winkel, De ontwikkelingsgang, p.353, 357 .

23. Van Haren, Leonidas, p.8. 
24. See Browning, The War of the Austrian Succession, p.42-4, 82-3.

25. Te Winkel, De ontwikkelingsgang, p.358, and D. C. Nijhoff, 'De staatsman-dichter Willem van Haren', Nederland 48 (I9OI), p.2I 2.

26. These poems - more than a hundred in total - were printed together in three volumes, entitled Verzameling der gedichten Van, voor en tegen jonkheer Willem van Haren (Amsterdam: A. Olofsen, I742).

27. Quoted from a letter by Willem Bentinck to the countess of Portland, Jane Martha Temple, dating from 5 February I744. See C. Gerretson and P. Geyl (eds), Briefwisseling en aantekeningen van Willem Bentinck, heer van Rhoon, vol. I (The Hague: Martinus Nijhoff, I976), p.92.

28. Anon., 'Gezang aan het Vereenigde Nederland', in Verzameling der gedichten, p.35-42.

29. R. Agricola, 'Rhytimologia belgica in Augustam Vindobonam', in Verzameling der gedichten, p.45-6.

30. The Latin and French translations were published by Isaac Beauregard in The Hague. It is not known who made these translations, although Jan te Winkel argues that Van Haren translated the poem into French prose in order to impress his acquaintance Voltaire. See Te Winkel, De ontwikkelingsgang, p.354.

3I. Nijhoff, 'De staatsman-dichter Willem van Haren', p.2I4.

32. Kees van Strien, Voltaire in Holland, I736-I745 (Louvain, Paris and Walpole, MA: Peeters, 2OII), p.I9o.

33. Nijhoff, 'De staatsman-dichter Willem van Haren', p.2I4-I5.

34. As Willem Bentinck put it, 'the great effect of the Leonidas, put the Magistrates in such a fright that they came into the augmentation of troops, for which there was an universal cry.' See Gerretson and Geyl, Briefwisseling, p.92.

35. For an extensive account of the negotiations that led to this decision, see P. Geyl, Willem IV en Engeland tot I748 (Vrede van Aken) (The Hague: Martinus Nijhoff, I924), p.83-Ioo.

36. Willem van Haren, Lof der vrede, in Derde vervolg der gedichten, p.39.

37. Joel Beeke, 'Martin Luther on Assurance', Quarterly Journal for Church Leadership 7 (I998), p.I66-7. We would like to thank Beatrice de Graaf for pointing us in this direction.

38. Beeke, 'Martin Luther on Assurance', p.44.

39. 'Men zal zich aan geen' Droom, geen yd'le vleyery/ Vergapen, om gerust en vergenoegd, en bly/ Zyn veiligheid op 't woord Van Koningen te vesten,/ Versmaders Van de rust en Van gemeenebesten!' Van Haren, Lof der vrede, p.20. Samuel Boyse's translation reads: 'Nor trust her Safety to such dubious Things, / The Word of Statesmen, or the Faith of Kings; / Whom History from long Experience knows,/ The Enemies of Freedom and Repose!' See The Praise of Peace: A Poem in Three Cantos. From the Dutch of M. Van Haren (London: A. Dodd, I742), p.35.

40. The Praise of Peace, p.I7-20.

4I. 'Maar is't dat Zy, die door de Volken zyn gesteld/ Om door hun magt den loop te stuiten Van 't Geweld,/ Traaghartig zyn in d'aan-betrouwden Staf te voeren,/ En hunnen pligt alleen aan hun belangen snoeren.' ('But if they, appointed by the people/ Fail to stop the approaching violence by their might/ Acting slowly in giving directions of administration/ Because they only observe duties that are connected to their interests': our translation). Van Haren, Lof der vrede, p.44.

42. Van Haren, Lof der vrede, p.45, 36.

43. The publication date of Van Haren's poem is uncertain; Samuel Boyse mentions its existence in July I742. The French translation of Van Haren's ode, published by Isaac Beauregard, is announced in the Leysche Courant of 3 September I742.

44. Willem van Haren, Aan de koninginne Van Hongaryen, in Derde vervolg der gedichten, p.IO3.

45. 'But I appreciate your courage/ Born in defence of Liberty, your thoughts are heroic' (our translation). See François de Voltaire, 'Voltaire au Monsieur Van Haren', in Het Frans gedicht van 
den Heere F. De Voltaire aan Jonkheer W.V. Haren, In het Nederduits vertaald en naagevolgd, door P. Merkman (Haarlem: J. Bosch, I743), p.3.

46. This is confirmed by Voltaire's letter to Jean-Jacques Amelot, written in The Hague on 2I July, in which he expresses the desire to win Van Haren's sympathy in favour of the French king. See Van der Sterre (ed.), Voltaire en de Republiek, p.I63-4.

47. Browning, The War of the Austrian Succession, p.24.

48. Nick Harding, Hanover and the British Empire, I7OO-I837 (Rochester, NY: Boydell and Brewer, 2007), p.I06-8.

49. Browning, The War of the Austrian Succession, p.99-I02.

50. Willem van Haren, Aan de Groot-Brittanische Natie, in Verzameling van gedichten door Jonkheer Willem van Haren, met Platen (Amsterdam: A. Olofsen, I742), p.47-8.

5I. See Willem van Haren, Aan zyne Groot-Brittannische Majesteit (The Hague: Isaac Beauregard, I743), p.A2 v.

52. Both letters are printed in Nijhoff, De staatsman-dichter Willem van Haren, p.38I-3.

53. 'The Character and Part of the Speech of Leonidas, from the Dutch of M. Van Haaren', The Gentleman's Magazine I2 (March I742), p.I56. The translation is attributed to Samuel Boyse by various scholars, such as Edward Hart, in 'Portrait of a Grub: Samuel Boyse', Studies in English Literature, I500-I900 7 (I967), p.4I9.

54. 'Many of them are scattered in The Gentleman's Magazine, marked with the letter Y. and Alceus.' See Robert Shiels, 'Samuel Boyse', in Robert Shiels and Theophilus Cibber (eds), Lives of the Poets of Great Britain and Ireland: To the Time of Dean Swift, vol. V (London: R. Griffiths, I753), p.I60-74.

55. 'Extracts of Mr. Van Haren's Love of Peace. A Poem', The Gentleman's Magazine I2 (May I742), p.270.

56. 'Y.', 'Ode addressed to M. Voltaire occasioned by his Ode in praise of the Queen of Hungary', The Gentleman's Magazine I2 (July I742), p.383.

57. 'Ode in Praise of the British Nation', The Gentleman's Magazine I2 (July I742), p.383-4.

58. For a legitimisation of this attribution, see Emily Lorraine de Montluzin, 'Attributions of $\mathrm{Au}-$ thorship in the Gentleman's Magazine, I73I -I868: A Supplement to the Union's List', www.bsuva. org/bsuva/gm2/GMintro.html [accessed 4 September 20I4].

59. A.F. Pollard, rev. Karen O'Brien, 'Ryder, William (I723-I785)', Oxford Dictionary of National Biography, www.oxforddnb.com/index/24/IOIO24405 [accessed 4 September 20I4].

6o. See The Gentleman's Magazine I3 (May I743), p.267. As had been clarified in The Gentleman's Magazine of November I742, the first translation had been accompanied by an explicatory note implying that the 'faithless foes' alluded to France. Van Haren, however, believed that the term should not refer to any specific national power. See p.6oo.

6I. The letter is printed in Alexander Chalmers, 'Samuel Boyse', in General Biographical Dictionary, vol. VI (London: J. Nichols, I8I2-I7), p.387.

62. 'Y.', 'To His Britannic Majesty on his Victory at Dettingen, June I6, I743', The Gentleman's Magazine I3 (June I743), p.438.

63. 'Y.', 'To Philargyrus', The Gentleman's Magazine I3 (July I743), p.438. The poem is a response to Rider's contribution 'Hymn to Virtue', which had been published in The Gentleman's Magazine I3 (June I743), p.376.

64. See Richard Ryan, 'Samuel Boyse', in Biographica Hibernica: A Biographical Dictionary of the Worthies of Ireland, from the Earliest Periods to the Present Time, vol. I (London: J. Warren, I8I9), p.I87; Chalmers, 'Samuel Boyse', p.383-7.

65. The Gentleman's Magazine I3 (May I743), p.267.

66. The Gentleman's Magazine I3 (May I743), p.267.

67. According to the Bibliothèque Nationale de France, a collection of Van Haren's poetry was published in French in I742, containing, among other things: 'Ode à la nation britannique', 'Trad. 
en prose de "Leonidas Herodot." lib. VII' and 'Ode à la reine de Hongrie.' This volume is listed as Lettrines et culs-de-lampe gr. sur bois; bandeau gr. sur cuivre par Jacob van der Schley, daté I742, à l'effigie de Marie-Thérèse d'Autriche (The Hague: Isaac de Beauregard, I742).

68. See Shiels, 'Samuel Boyse', p.I69-70.

69. This letter is cited at length in 'The Life of Boyse', in Robert Anderson et al. (eds), A Complete Edition of the Poets of Great Britain, vol. X (London: John and Arthur Arch, I795), p.329.

70. Leonidas, Tiré du septième Livre de Herodote, Traduit de Hollandois de Mr. de Haren. See the previously mentioned Lettrines et culs-de-lampe gr. sur bois.

7I. See 'Y', 'The Character and Part of the Speech of Leonidas, from the Dutch of M. Van Haaren', p.I56.

72. 'This breast shall native freedom n'er resign!/ Alone this hand the honest weapon draws,/ And joys to perish in so just a cause! perish in so just a cause.' ' $\mathrm{Y}$ ', 'The Character and Part of the Speech of Leonidas'.

73. 'Ik zal dan, wil niemand met my sterven,/ Alleen, alleen het Oorlogs-Zwaard/Opheffen, en alleen de Vryheid met myn leven Beschermen.' See Van Haren, Leonidas, p.8.

74. 'Seul j'irai,/ Sans craindre la mort,/ Sacrifier ma vie pour la liberté'. See Leonidas, Tiré du septième livre, p.7.

75. Van Haren writes: 'Maar wat, wat deert dit ons? Wy die 't Gemeenebest/ Van Neêrland door de gunst des Hemels nog betreden,/ En geen'Monarch, geen'Vorst begeeren in onz'steeden.' (But what should this matter to us/ Who live in the commonwealth/of the Netherlands, by Heavenly grace/ And who do not desire a monarch or Royal power to rule over our cities': our translation). See Van Haren, Lof der vrede, p.29.

76. Boyse, The Praise of Peace, p.45.

77. Boyse, The Praise of Peace, p.3I.

78. Boyse, The Praise of Peace, p.46.

79. 'Hy Blikzemt slag op slag;/ En smelt de Sneeuw die lange op 't hoogst der Bergen lag/ 't Ontzachelyk geluid doed de Aarde allomme beven.' See Van Haren, Lof der vrede, p.7o.

80. Boyse, The Praise of Peace, p.44.

8I. Richard Ryan, 'Samuel Boyse', p.I8o.

82. Shiels, 'Samuel Boyse', p.I73.

83. Shiels, 'Samuel Boyse', p.I7I .

84. Shiels, 'Samuel Boyse', p.I70.

85. The Gentleman's Magazine I2 (January I742), p.32-3.

86. The Gentleman's Magazine I2 (April I742), p.I87.

87. See James Mullala, A View of Irish Affairs since the Revolution of I688: To the Close of the Parliamentary Session of I795, vol. I (Dublin: T. Hensall, I795), p.229.

88. For the controversy over Wood's halfpennies, see Patrick Kelly, 'Swift on Money and Economics', in Christopher Fox (ed.), The Cambridge Companion to Jonathan Swift (Cambridge: Cambridge University Press, 2003), p.I28-45.

89. See David Hayton, Ruling Ireland, I685-I742: Politics, Politicians and Parties (Woodbridge: Boydell Press, 2004), p.270-75.

90. Samuel Boyse, 'To the Right Honourable, The Lord Carteret, on his First Arrival in Ireland, Anno I725', in Translations and Poems on Several Subjects, p.79-8I .

9I. See Tony Claydon, William III: Profiles in Power (London: Routledge, 20I4), and S. J. Connolly, Religion, Law and Power: The Making of Protestant Ireland, I660-I760 (Oxford: Oxford University Press, I992).

92. Boyse, The Praise of Peace, p.46.

93. The Gentleman's Magazine I3 (July I743), p.378. 
94. Mullala, A View of Irish Affairs, p.243.

95. Patrick Griffin, The People with No Name: Ireland's Ulster Scots, America's Scots Irish, and the Creation of a British Atlantic World, I689-I764 (New York: Princeton University Press, 200I), p.65. 96. See Hayton, Ruling Ireland, I685-I742, p.275.

97. For further reading on this famine, see Donald E. Jordan, Land and Popular Politics in Ireland: County Mayo from the Plantation to the Land War (Cambridge: Cambridge University Press, I994), p.43-4.

98. Mark McLaughlin, The Wild Geese: The Irish Brigades of France and Spain (Oxford: Osprey Publishing, I980), p.II.

99. Samuel Johnson, 'Preface to Shakespeare', in Walter Raleigh (ed.), Johnson on Shakespeare (Oxford: Henry Froude, I908), p.I6.

Ioo. 'Publicus', 'To the Printer of the Daily Gazetteer', The Gentleman's Magazine I8 (July I748), p.3I6-I7. In I746 another fragment of Boyse's translation had been published: 'The Praise of Peace, in Three Cantos', The Gentleman's Magazine I6 (December I746), p.637.

LOTTE JENSEN is Associate Professor of Early Modern Dutch literature at Radboud University Nijmegen and Principal Investigator of the 'Proud to be Dutch' research project, for which she was awarded a grant by the Dutch Research Council, NWO. This project investigates the shaping of a Dutch national identity between I648 and I8I5.

MARGUERITE CORPORAAL is Associate Professor of British Literature at Radboud University Nijmegen. She is the Principal Investigator and coordinator of the 'Relocated Remembrance: The Great Famine in Irish (Diaspora) Fiction, I847-I92I' research programme, for which she was awarded a Starting Grant by the European Research Council. 